NBER WORKING PAPER SERIES

\title{
IS CROWDING OUT DUE ENTIRELY TO FUNDRAISING? EVIDENCE FROM A PANEL OF CHARITIES
}

\author{
James Andreoni \\ A. Abigail Payne \\ Working Paper 16372 \\ http://www.nber.org/papers/w16372 \\ NATIONAL BUREAU OF ECONOMIC RESEARCH \\ 1050 Massachusetts Avenue \\ Cambridge, MA 02138 \\ September 2010
}

This research was supported by grants from the National Science Foundation, from the Social Sciences and Humanities Research Council of Canada, the Canada Foundation for Innovation, and the Ontario Innovation Trust. We would also like to thank the Urban Institute for providing us with access to the IRS 990 data set. We're grateful to Justin Rao and participants in various seminars and conferences for helpful comments. The views expressed herein are those of the authors and do not necessarily reflect the views of the National Bureau of Economic Research.

NBER working papers are circulated for discussion and comment purposes. They have not been peerreviewed or been subject to the review by the NBER Board of Directors that accompanies official NBER publications.

(C) 2010 by James Andreoni and A. Abigail Payne. All rights reserved. Short sections of text, not to exceed two paragraphs, may be quoted without explicit permission provided that full credit, including (C) notice, is given to the source. 
Is Crowding Out Due Entirely to Fundraising? Evidence from a Panel of Charities

James Andreoni and A. Abigail Payne

NBER Working Paper No. 16372

September 2010, Revised January 2011

JEL No. H3,H41,H44

\begin{abstract}
$\underline{\text { ABSTRACT }}$
When the government gives a grant to a private charitable organization, do the donors to that organization give less? If they do, is it because the grants crowd out donors who feel they gave through taxes (classic crowd out), or is it because the grant crowds out the fund-raising of the charities who, after getting the grant, reduce efforts of fund-raising (fund-raising crowd out)? This is the first paper to separate these two effects. Using a panel of more than 8,000 charities, we find that crowding out is significant, at about 72 percent. We find this crowding out is due primarily to reduced fund-raising. Depending on which types of organizations are included in the analysis, crowding out attributable to classic crowd-out ranges from $30 \%$ to a slight crowd-in effect, while fund-raising crowd out ranges from $70 \%$ to over $100 \%$ of all crowd out. Such a finding could have important consequences for how governments structure grants to non-profits. Our results indicate, for example, that requirements that charities match a fraction of government grants with increases in private donations might be a feasible policy that could reduce the detrimental effects of crowding out.
\end{abstract}

James Andreoni

Department of Economics

University of California, San Diego

9500 Gilman Drive

La Jolla, CA 92093-0508

and NBER

andreoni@ucsd.edu

A. Abigail Payne

Department of Economics

McMaster University

KTH 426, 1280 Main Street West

Hamilton, Ontario, Canada L8S 4M4

paynea@mcmaster.ca 


\section{Introduction}

When the government gives a grant to a private charitable organization, how much will this displace private donations? This is known as the crowding out problem and is one of the oldest and most important questions in public economics. ${ }^{1}$

The classic theory of crowding out is that individual donors, who are also often tax payers, will treat their voluntary private contributions as a substitute for their involuntary contributions through taxation and, as a result, reduce giving to a charity by the full amount of the grant. For this explanation to have traction, donors must treat their gift and the government's contribution as substitutes. A growing body of evidence from both experimental and survey data, however, questions this assumption. ${ }^{2}$ The theory also requires that donors are aware of the fluctuations in government grants received by the charity and respond accordingly. While such information eventually becomes publicly available through tax filings of the charities, using IRS form 990, it may not be available to the donors at the time of their contributions.

The classic theory also ignores an important aspect of reality, namely fund-raising. Fund-raising is a significant undertaking. A typical charity will spend from 5 to 25 percent of its donations on further fund-raising activities. ${ }^{3}$ While these activities may be profitable for the organizations, managers of nonprofits are forbidden by law from capturing any of this surplus for themselves. Charity managers, therefore, may see fund-raising as a "necessary evil” and, given the chance, might prefer to divert fund-raising resources to their charitable activities. ${ }^{4}$ Moreover, donors and charity watch-dog groups often perceive large fund-raising expenses,

\footnotetext{
${ }^{1}$ See Clotfelter (1985) and Andreoni (2006) for reviews and perspectives on crowding out.

${ }^{2}$ Andreoni $(1989,1990)$ provides some of the early theoretical contributions, recent empirical evidence comes from Ribar and Wilhelm (2002), recent experimental evidence can be found in Andreoni (2007), and neurobiological evidence is found in Harbaugh, Mayr, and Burghart (2007). Andreoni (2006) reviews this literature.

${ }^{3}$ See Andreoni (1998) for a discussion of fund-raising expenditures by charities in the Unites States.

${ }^{4}$ This hypothesis for why charities may not maximize net revenues was first offered by Weisbrod (1988) and since has been explored by several others. We discuss this in more detail later in the paper.
} 
rightly or wrongly, as indications of a low-quality charity. Charity Navigator, for instance, gives its lowest rating to a food bank or community foundation that raises fewer than $\$ 5$ for every dollar spent on fund-raising. ${ }^{5}$ Since both donors and managers seem predisposed to dislike fundraising, a grant to a charity may also crowd out its fund-raising activities. This gives a second indirect way that grants could reduce giving—charities may spend less effort on raising money.

This paper is the first to both estimate crowd out and to decompose it into classic crowding out and indirect crowding out due to reduced fund-raising. Why is this endeavor important? First, crowding out is a hidden cost to government grants, and it is important to understand its magnitude and its causes. Second, our answers may inform behavioral models of both donors (are they warm-glow givers?) and charitable firms (are they net revenue maximizers?). Third, the nature of crowding out can have significant consequences for potential government policies toward charities and fund-raising. Suppose, for instance, that in an attempt to mitigate crowding out the government required that spending by the organization go up by the full amount of the grant, that is, it legislated zero crowding out. If crowding out is entirely due to reduced fund-raising, then this policy is feasible. If, by contrast, crowding out is purely classic and charities are behaving optimally, then the government may be powerless to stop the ill effects of crowding out. Hence, if we are able to find a significant fraction of crowding out is in fact due to endogenous responses of the charity, it expands the policy tools available to a government wishing to maximize the benefits of the tax dollars spent.

We study crowding out and its causes with a panel of tax returns from charitable organizations. We begin with a sample of more than 40 thousand organizations. After excluding organizations that never report private donations, government grants, or fund-raising expenditures and/or appear to have extreme values, we analyze a sample of more than 8,000

\footnotetext{
${ }^{5}$ See the Charity Navigator web site http://www.charitynavigator.org/index.cfm, under "methodology.”
} 
organizaitons and close to 40 thousand observations. Our estimates show significant crowding out of about 73 percent-every $\$ 1000$ grant reduces giving by $\$ 727$. This figure is slightly higher than in prior studies. However, it is robust to a number of different instruments and the inclusion/exclusion of different types of organizations. Most importantly, we find that most of the crowding out is the result of reduced fund-raising. In our preferred specification, all of the crowd-out is attributable to fund-raising. There is no evidence of classic crowding out-in fact we measure a slight crowding in of donors by government grants. If we exclude some groups of organizations, the results suggest that the crowding out attributable to fund-raising is substantial but not complete.

Another interesting finding of our analysis is that charitable fund-raising is highly profitable, with over $\$ 5$ raised per dollar spent on fund-raising. While this number may strike economists used to profit maximization as somewhat high, it is perfectly in line with ideals of best practices promulgated by the charity watchdog groups and fund-raising professionals, as we show below. That is, while economists see this finding surprising, industry experts would find this return to fund-raising to be just as expected. Below we provide some speculation on the kinds of factors that could explain the effectiveness of fund-raising.

The most important implication of our findings is that they open up a broader set of policy alternatives to the government. According to our estimates, a $\$ 1,000$ increase in grants will result in classic direct crowding in of $\$ 45$, reduced fund-raising expenditures of $\$ 137$, and indirect crowding out due to reduced fund-raising of $\$ 772$. As a result of the $\$ 1,000$ grant, total contributions to the charity fall by $\$ 727$, and the charity nets $\$ 410$ including the money it saves on fund-raising. If charities were required to maintain current fund-raising expenditures and 
practices, the charity would would not only preserve its prior donations but also gain $\$ 45$ in revenue resulting from a slight crowd-in affect of the grant.

This paper is organized as follows. Next we give a brief background to the literature on crowding out, including the motivation for our approach. Section 3 describes the data. Section 4 discusses the estimation strategy and section 5 presents the results. Section 6 is a conclusion.

\section{Background}

The classic model of crowding out, as presented in Warr (1982), Roberts (1984), and Bergstrom, Blume, and Varian (1986), is derived from the assumption that individuals see their own contribution as a perfect substitute for dollars given by the government. Andreoni (1988) showed that this model of "pure altruism" is unable to explain many simple facts about giving, and also leads to extreme predictions, such as that consumption is independent of redistributions of income. A model of impure altruism that assumes individuals experience some joy of giving, or a "warm-glow" (Andreoni, 1989, 1990, Steinberg, 1987, Cornes and Sandler, 1984), naturally leads to incomplete crowding out. Empirical research, as shown by Ribar and Wilhelm (2002), has been more consistent with a model of warm-glow giving than of pure altruism.

There are many empirical studies on crowding out, and most show that crowding is quite small, often near zero, and sometimes even negative (crowding in). Notable studies include Kingma (1989), Okten and Weisbrod (2000), Khanna, Posnett and Sandler (1995), Manzoor and Straub (2005), Hungerman (2005), Borgonovi (2006), and Gruber and Hungerman (2007). Payne (1998) noted that the government officials who approve funding for the grants are elected by the same people who make donations to charities. This means that positive feelings toward a charity will be represented in the preferences of both givers and the government, and that this simultaneity could bias findings against crowding out and could even lead to biased predictions 
of crowding in. For instance, a hurricane that causes both public and private charity to rise could create this positive bias. Payne (1998), using a panel of charities drawn from IRS 990 forms, addresses this with two-stage least squares analysis. She uses aggregate government transfers to individuals in the state as an instrument for government grants and finds that estimates of crowding out rise from zero in OLS to around 50 per cent in 2SLS.

Andreoni and Payne (2003) ask the simple question: what happens to a charity's fundraising expenses when it gets a government grant? They first provide a theoretical framework that predicts that charities that compete for donors will reduce fund-raising efforts in response to a grant, due partly to classical crowding and partly to substituting efforts away from fund-raising and into their charitable services. For the empirical analysis, they again looked at IRS 990 filings, this time on a 14-year panel of 233 arts organizations and 534 social services organizations. As with Payne’s (1998) earlier observation, charities that are in high demand will likely receive government grants and engage in active fund-raising. This again requires an instrumental variables approach. Their results imply that a $\$ 1000$ increase in grants will reduce fund-raising for the arts by $\$ 265$, and for social services by $\$ 54$. These effects are significant; grants decrease fund-raising by about 52 percent for arts organizations and 32 percent for social service organizations.

The next natural step in this research is to measure crowding out and ask what fraction of this is due to reduced fund-raising as opposed to classic direct crowding out. We address this question next. 


\section{The Nonprofit Data Set}

The data on nonprofit revenues and expenses come from federal tax returns filed by IRS Section 501(c)(3) organizations for the period 1985 to 2002. ${ }^{6}$ Representing the largest part of the nonprofit sector, 501(c)(3) nonprofits are those organizations whose purposes are religious, charitable, educational, scientific, or related to public safety testing. ${ }^{7}$ The tax returns identify the amount the nonprofit received in private donations, government grants, and fund-raising expenditures for the year for which the return was filed. Private donations may come from individuals, estates, corporations, and/or other nonprofit organization. Government grants include grants received from all levels of government, excluding reimbursements for services provided by the nonprofit under a government contract. $^{8}$

Prior to 1998, only a random sample of IRS 990 filings (stratified based on the income of the charity) were available. Starting in 1998, all IRS 990 filings were digitized and made available by the National Center for Charitable Statistics. The organizations have been classified in the National Taxonomy of Exempt Entities. We constructed an unbalanced panel data set for organizations operating in the 48 contiguous United States in human service, children and family related service, poverty, housing and food related, and other types of social service. ${ }^{9} \quad$ As in our

\footnotetext{
${ }^{6}$ The data were obtained from the Urban Institute's National Center for Charitable Statistics. For a given year, the returns are for firms whose accounting period ended between November of that year and October of the following year. We brought together data from two samples. The first sample covers the period from 1982 to 1997, although for this analysis we pulled only the data for 1985 and beyond. The sample is stratified based on the asset size of the non-profits. Most of the returns tracked are for non-profits with assets that exceed $\$ 500,000$. For each year, IRS randomly sampled the non-profit firms within each asset level. As IRS's budget for this study increased, the number of non-profit organizations tracked for a given year also increased.

${ }^{7}$ An organization is required to file a tax return if its annual gross receipts are greater than $\$ 25,000$ and it is not a religious organization.

${ }^{8}$ These types of payments are reported on a non-profit's tax return under program service revenue. Program service revenue, however, is not limited to payments by the government; it covers any payment received by the non-profit for the services provided.

${ }^{9}$ We used the NTEE classification as it existed in 2005 and kept those firms with a 1-digit classification of I, J, K, L, $\mathrm{P}$, or S. Initially we included firms with an NTEE classification of C (environment) and O (Youth Development). Including these types of organizations in the analysis tended to pull the results to an extreme. We suspect this is due to greater variability in the role played by government funding and the nature of the goods/services provided. We
} 
earlier work (2003), we exclude firms if government grants, private donations, or fund-raising are always zero $\left(27,630\right.$ firms). ${ }^{10}$ We also only kept firms with at least three years of observations. We drop firms based on the following rules: organizations that never received a private donations during the period for which we have digitized data (23 organizations); organizations with extreme private donations in one year relative to the private donations received in other years (4 organizations); only 1 year of positive fund-raising expenditures (3950 organizations); 3 or more years of 0 fund-raising (3 organizations); or a reporting of 0 for both liabilities and total occupancy expenses for all years as these are measures being used to predict an organization's fund-raising expenditures (1770 organizations). Of these additional reasons for excluding firms from the analysis, only the exclusion of firms with extreme private donations and the firms with only one year of reported fund-raising expenditures dramatically affect the significance and/or magnitude of the key coefficients.

Our initial sample contained 41,442 organizations with three or more years of observations. After excluding organizations as reported above we are left with a sample of 8,062 charities, and a total of 39,769 observations. All of the dollars are constant (base year 2000). Overall, the charities average $\$ 787$ thousand in donations, about $\$ 907$ thousand in government grants, and spend about $\$ 91$ thousand on fund-raising (12\% of donations). A summary of the data is shown in Table 1. Reliance on private donations and government grants varies across the different types of organizations.

therefore excluded these organizations from the primary analysis. In Table 5, however, we test the sensitivity of our results and show the results if we include either of these types of organizations.

${ }^{10}$ Excluding firms that never report a positive level of fundraising expenditures is done in order to include only those firms that can refute the hypothesis that grants reduce fundraising. To include firms without fundraising expenditures over the entire panel would not inform our hypothesis and could lead to biased conclusions. 


\section{Estimation Strategy}

To identify the effects in which we are interested, we need to find three relationships. First, we need to know how donations respond to grants, controlling for fund-raising. Second, we need to know how donations respond to changes in fund-raising, controlling for grants. Third, we need to know how fund-raising responds to changes in grants. A challenge for our estimation is the issue of endogeneity. Unobserved characteristics or events could cause donations, grants, and fund-raising to be correlated. For instance, imagine a natural disaster that makes many people homeless. We are likely to see both giving and grants increase as a result, which would lead to positive biases in the effects of grants on donations. Fund-raising will also be affected by such events, but the potential bias is less clear. If, in this example, the need becomes greater then fund-raising may rise, but if people become more generous when asked for a donation then fund-raising may actually fall. It will be important, therefore, to find instruments for both fund-raising and grants.

Ideally, we would estimate the following equations directly:

$$
\begin{aligned}
& \text { Donations }_{i c t}=\alpha_{i}+\lambda_{t}+A \cdot \text { GovtGrants }_{i s t}+B \cdot \text { Fundraising }_{i s t}+\text { Controls }_{i s t} \omega+\varepsilon_{i s t} \\
& \text { Fundraising }_{i c t}=\rho_{i}+\varphi_{t}+C \cdot \text { GovtGrants }_{i s t}+\text { Controls }_{i s t} \kappa+\eta_{i s t}
\end{aligned}
$$

In the first equation, private donations (of charity $i$ in state $s$ at time $t$ ) are regressed on government grants, fund-raising costs, firm and year fixed effects, and a set of firm, and state level controls. In this equation, we are concerned about the endogeneity of government grants, the relationship between fund-raising expenditures (equation 2) and government grants, and omitted variables that are correlated with private donations and government grants or fund- 
raising expenditures. ${ }^{11}$ This estimation naturally suggests an analysis with three stage least squares, where we estimate a two equation system with fund-raising as a function of grants, and donations as a function of both grants and fund-raising.

Wooldridge (2002) cautions, however, that there are disadvantages to a systems estimation of (1) and (2) above. For a system method to estimate the coefficients consistently, all equations in the system must be properly specified. If this cannot be assured, then 3SLS or GMM will not be consistent and single equation estimation, such as 2SLS is more robust. ${ }^{12}$ We therefore opted to take a more conservative approach and rely on a reduced form two stage least squares analysis. We estimate separately the following three equations:

$$
\begin{aligned}
& \text { Donations }_{i s t}=\alpha_{i}^{1}+\lambda^{1}{ }_{t}+A \cdot \text { GovtGrants }_{i s t}+\text { Controls }_{i s t} \omega^{1}+\varepsilon^{1}{ }_{i c t} \\
& \text { Donations }_{i s t}=\alpha_{i}^{2}+\lambda^{2}{ }_{t}+B \cdot \text { Fundraising }_{i s t}+\text { Controls }_{i s t} \omega^{2}+\varepsilon^{2}{ }_{i c t} \\
& \text { Fundraising }_{i s t}=\rho_{i}+\varphi_{t}+C \cdot \text { GovtGrants }_{i s t}+\text { Controls }_{i s t} \kappa+\eta_{i c t}
\end{aligned}
$$

For all specifications, we use the following controls: program dues revenues collected by the charity, state level individual per capita income, state population, state population squared, the share of the population under the age of 18 , the share of the population over the age of 65 , annual state level expenditures for Medicare, Medicaid, and income assistance, a dummy variable equal to one if the governor is affiliated with the Democratic party, the share of US Congressional representatives for the state affiliated with the Democratic party, a year trend

\footnotetext{
${ }^{11}$ It is important to ask here whether fund-raising expenditures include costs of applying for grants. As we discuss in detail in our first paper (Andreoni and Payne, 2003), these costs can be included on the 990 form under fundraising expenditures, however, these expenses are not contemporaneous to receiving or even anticipating the receipt of the grant money. Hence, grants had a substantial impact on, for instance, professional fund-raising expenses, but no discernable impact on officers salaries devoted to fund-raising. This indicates that grant-writing costs are are likely not coloring the marginal effects of grants on fund-raising.

${ }^{12}$ Wooldridge (2002, p. 222 ) states, "When estimating a simultaneous equations system, it is important to remember the pros and cons of full system estimation. If all equations are correctly specified, system procedures are asymptotically more efficient than a single-equation procedures such as 2SLS. But single-equation methods are more robust. If interest lies, say, in the first equation of a system, 2SLS is consistent and asymptotically normal provided the first equation is correctly specified and the instruments are exogenous. However, if one equation in a system is misspecified, the 3SLS or GMM estimates of all the parameters are generally inconsistent.”
} 
interacted with the NTEE1 code, and a set of year dummies (one for the period prior to 1998 and separate measures for each year subsequent to 1998). These measures help to control for changes that are occurring in the state and overall that could affect charity operations. Also included are organization fixed effects which capture time-invariant characteristics of the charities and the areas in which a charity is located.

Because equation (1) has been broken into two estimations, we need instruments that explain government funding and instruments that explain fund-raising expenditures. Our approach is similar to that of Gruber (2004) and Gruber and Hungerman (2007). We can use our estimates from these three regressions to derive our desired predictions. The coefficient $A$ on government grants from the estimation of equation (3) will tell us the total crowd out, combining both the direct and indirect effects. The coefficient $B$ on fund-raising expenditures from the estimation of equation (4) will tell us the productivity of each dollar of fund-raising. Finally, the coefficient $C$ on government grants from the estimation of equation (5) will tell us how much fund-raising falls when grants are received.

We can use these coefficients to decompose the total effect, $A$. An additional dollar of grants will reduce fund-raising by $C$ dollars, and each dollar of decreased fund-raising results in $B$ dollars less in giving. Hence, the indirect change in donations from reduced fund-raising is $B^{*} C$, which then means the direct crowding out effect is $A-B^{*} C$.

Notice that if fund-raising falls, then the charity also conserves some money that would have gone to fund-raising, and can spend this on services. Thus, if we want to discuss crowding out of spending rather than giving, we would call the total effect $A-C$, and the indirect effect $B^{*} C-C$. The direct effect stays the same, $A-B^{*} C$. 


\subsection{Instruments for Government Grants}

We need instruments that are correlated with government grants, but not with private donations or fund-raising expenditures. We include, as control variables, measures to reflect the political party affiliation of the state governor and the distribution of Congressional representatives by political party affiliation for the state in which the firm is located. Our instruments exploit variation in the Congressional representation that is associated with the tenure of these representatives. First, we calculated the total seniority of the representatives for a state by political party affilication. ${ }^{13}$ Since elections occur every two years, we get some time variation. We also get variation in state compositional changes due to redistricting after both the 1990 and 2000 censuses.

We look to these political variables for instruments because the power (as represented by tenure) of a politician in Congress may be important in bringing federal dollars to the district, including grants to charitable organizations. Power, however, may also be associated with whether a given political party has a majority of the members representing a state. We, therefore, create a third measure that is the difference between the total tenure of the majority party for the state representatives and the total tenure of the minority party for the state representatives. From these three measures we report the results for the instruments for the government grants consisting of the total seniority of the members affiliated with the Democratic party and the difference between the seniority of the members with the most and least Congressional representatives.

Table 2 reports the summary statistics for these instruments. Column 1 of Table 3 reports the coefficients for the instruments used to predict government grants in the first stage regression. The coefficient on the seniority of the Democratic representatives is negative,

\footnotetext{
${ }^{13}$ Initially we explored the use of political measures that captured representation of voters in the county in which the firm is located. At this level of analysis, however, this is little variation in the political measures given most firms are observed between 1998 and 2002, a fairly short period for exploiting county level political turnover in Congress.
} 
suggesting an extra year of representation reduces government grants by $\$ 3.6$ thousand. The coefficient on the measure that reflects the difference between members with greater and lesser representation in Congress is also negative. This latter coefficient suggests that charities in states with greater power and/or more representatives affiliated with a single political party will have lower levels of government grants. The F-statistics on the joint significance of the instruments is 7.13.

Initially these results may not seem intuitive. Recall that a control measure is the share of Congressional representatives affiliated with the Democratic Party. The coefficient on this control measure is positive, suggesting the within charity effect of an increase in the share of Democratic representatives is positive. The seniority measures used as instruments capture the additional increases (decreases) that are attributable to having more senior members of Congress representing the state. There are several political economy stories that could justify either a positive or negative coefficient. For example, it may be that with more senior members in Congress, the connection between government grants and social service organizations falls because the funding for goods and services associated with social service provision flows directly to individuals and/or through programs that involve direct government provisions.

\subsection{Instruments for Fund-raising Expenditures}

Finding instruments that explain fund-raising but do not directly explain either the propensity of individuals to donate or government grants is challenging. Our approach was to identify a set of measures that reflects the financial security of the organization. Arguably, if an organization is facing increasing expenses, it will change its fund-raising efforts in response. We rely on measures of each charitable organization that are reported on the IRS 990 forms. The instruments we considered are, first, total liabilities of the organization and, second, total 
occupancy expenses, which reflects expenses for office space, heating, and other utilities (excluding telephone).

Table 2 provides means and standard deviations of the instruments used in the analysis. The coefficients on these instruments in the first stage regression are reported in column 3 of Table 3. The F-statistic from the joint significance of the instruments is quite high, 17.47. An increase in both expenses results in an increase in fund-raising expenditures. The reader may be concerned that the financial health of a charity may also affect private donations and/or government grants. We believe, however, that contemporaneous information on the financial well being of a firm at the time a donation or grant is being given is difficult to ascertain. Donors are likely to only perceive the general well-being of the charity. This perception is controlled for through the use of the organization fixed effects. In contrast, the charitable organization is likely to be keenly aware of its finances and, thus, should be expected to modify it fund-raising efforts to deal with changes in its financial health. From a statistical perspective, as discussed below, we ran various tests for over, under, and weak identification of the instruments and estimated the second stage regression using 2SLS, GMM, and LIML specifications.

\section{Estimation}

The results of our analysis are reported in Table 4. For the IV specifications, we report the statistics for the test of over-identifying restrictions for the instruments. While we do not report them in the table, for all of the IV specifications, the Cragg-Donald F-statistics are greater than the Stock-Yogo weak identification test critical values and the Anderson canonical correlations likelihood ratio tests are satisfied. 
For each equation we report the results under three methods of IV estimation: limited information maximum likelihood (LIML), two stage least squares (2SLS), and generalized method of moments (GMM). As with any IV estimation, weak instruments are an issue. Moreover, the tests for the strength of instruments are indicative but not conclusive. If the instruments are weak, that is the correlation between the instruments and the endogenous measure is small, then our results would be misleading (see e.g. Bound, Jaeger, and Baker, 1995). The three methods reported (LIML, 2SLS, and GMM) have different strengths and weaknesses. Our preferred specification is one that uses LIML as the properties attributable to LIML help to address issues related to weak instruments. As will be revealed below, however, our estimates are similar across all three methods.

Effects from a change in government grants on private donations (A): Panel A

The results under an OLS specification are reported in column $1 .{ }^{14}$ We can see clear evidence here of the endogeneity bias discussed earlier. In Panel A, government grants would appear to crowd-in charitable contributions, which indicates a clear positive bias in this coefficient, as predicted. In column 2 we report the results for instrument set 1 for government funding and fund-raising expenditures using a limited information maximum likelihood (LIML) method of estimation. In column 3 we report the results for instrument set 2 for government funding, also under a LIML estimation method. In columns 4 and 5 we report the results using instruments set 2 for government funding and the instrument set for fund-raising under a 2SLS and GMM estimation method, respectively. ${ }^{15}$

\footnotetext{
${ }^{14}$ For all of the specifications we report robust standard errors. Stock and Watson (2006) suggest that robust standard errors may be preferable to clustered standard errors under a fixed-effects estimation when the number of firms is large and the number of observations per firm is short.

${ }^{15}$ The 2SLS, GMM, and LIML estimations were performed using the xtivreg2 program developed by Schaffer (2007).
} 
Across the estimations, the over-identification test is satisfied. Overall, the estimates suggest the total crowd-out of private donations is approximately 76 percent. These estimates are consistent with Payne (1998), whose estimates ranged from 50 to 78 percent.

\section{Effect of fund-raising expenditures on private donations (B): Panel B}

In the instrumental variable regressions, the over-identification test is satisfied. We find coefficients ranging from 5.6-5.7, indicating that, on average, a marginal dollar spent on fundraising yields over five dollars in new donations. This shows that charities are not net-revenue maximizers, but rather leave considerable slack in their fund-raising potential. This is similar to observations of Weisbod and Dominguez (1986) who generally find "fund-raising elasticities" of greater than one for the types of charities we consider here. Our estimates are consistent with the notion of Weisbrod $(1988,1998)$ that charities stop once revenue goals are met and do not maximize net revenues. Instead, they appear to be more closely in line with the benchmarks of best practices promulgated by industry experts and watchdogs.

Effect from a change in government grants on fund-raising expenditures (C): Panel C

In the instrumental variable regressions, the over-identification test is clearly satisfied. The estimates suggest that fund-raising efforts are reduced by 14 cents per dollar of government grants received. Again, these estimates are consistent with earlier findings of Andreoni and Payne (2003) who found coefficients of -0.019 to -0.265 .

\section{Decomposition of Crowd-Out Effect}

In Column 1 of Table 5 we combine our results to separate the total crowd out into the classic direct crowd out and the indirect crowd out due to reduced fund-raising. The top three rows of Table 5 reproduce the essential parts of Table 4 used in our calculations using the LIML specification and the best set of instruments. The middle panel provides examples combining the 
within-column coefficients to produce a sample of estimates for direct and indirect crowding out of donations. Across the columns that report the results using an instrumental variables strategy, our results suggest that most of the crowd-out is attributable to a decline in fund-raising. Approximate 105 percent of crowd-out is from reduced fund-raising. The direct behavior of individual donors is slightly positive, suggestion a slight crowd-in effect by private donors. The crowd-in could, for instance, be due to a signal of quality generated by a government grant, or because the grant allowed for a significant increase in the scale or scope of the organization, thus allowing fundraisers to reach more people.

Importantly, our results support the notion that donors are not completely aware of fluctuations in grants received by the charity or, if they are, the grants do not discourage their giving.

The results just discussed slightly overstate the problem of crowding out. The reason is that if charities reduce fund-raising, then there is money conserved that can be devoted to charitable services. Hence, we may want to add to the direct crowding the marginal savings in fund-raising expenses. In the notation used in section 4 , this means crowd out is $A-C$ rather than simply A. The final three rows of Table 5 illustrate crowding out in this case. Since the change in dollars of fund-raising is small relative to the total crowd out, this approach reduces the indirect crowd out by 6 percentage points, our estimate of indirect crowding to 62 percent of the total.

\section{Robustness of Results}

Through our transforming the data and our testing of instruments and different specification we discovered that there are many organizations that report arguably extreme (or incorrect) donations, grants, and/or fund-raising expenditures. With more than 8000 
organizations, hand checking each organization and trying to verify the information with third party sources is impractical. Therefore, to explore the sensitivity of the results we took two steps. First, we varied our instruments. With slight variations (e.g. including non-linear terms of our instruments), the results are robust. Second, we excluded/included groups of organizations into our analysis. Columns 2-11 of Table 5 summarize our results from this exploration. In Column 2, we included organizations that report positive private donations and fund-raising expenditures but never report a positive level of government grants over the sample period. This increases the sample size to 14,354 organizations and 71,740 observations. Including these additional charities increases the total crowd-out by approximately 10 percent; and the crowd-out attributable to fund-raising behavior also increases. The effect of fund-raising on private donations, decreases slightly. Overall, including these organizations increases the standard errors but does not change the conclusion that the bulk of crowding out is attributable to a decline in fund-raising behavior.

In columns 3-7 of Table 5, we excluded organizations from the analysis based on their NTEE 1 coding. ${ }^{16}$ Excluding just one group of organizations changes the estimation of crowdout and the allocation of the crowd-out between direct and indirect channels. For example, if we exclude the charities that are classified as crime or legal related (NTEE 1 code "I"), the total crowd-out is reduced to 55 percent. Approximately 80 percent of the crowd-out is attributable to a decline in fund-raising and 20 percent is attributable to a decline in private donations. Overall, excluding the different types of organizations suggests that total crowd-out ranges between 55

\footnotetext{
${ }^{16}$ We report the results for the exclusion of all groups except the human services group (NTEE code "P") of charities. As the human services group represents the bulk of the organizations under study, it is not surprising to observe that if we exclude these organizations the power of the instruments used in the analysis diminishes.
} 
and 77 percent. The indirect crowd-out attributable to a decline in fund-raising ranges between 42 and 73 percent, or between 80 and 132 percent of total crowd-out. The direct reaction by private donors ranges between a crowd-out of 20 percent and a crowd-in of 32 percent

Recall, our preferred specification excludes charities that have are classified as environmental or youth development. In columns 8 and 9 of Table 5 we report the results from the estimations that include these organizations. If we include environmental organizations (column 7), total crowd-out is more than dollar for dollar, $126 \%$. The crowd-out attributable to a decline in fund-raising is close to dollar for dollar and the crowd-out directly attributable to a decline in private donations is approximately 28 percent. If we include youth development organizations (column 9), total crowd-out is also more than dollar for dollar (124\%). Most of the crowd-out is attributable to a decline in fund-raising and the crowd-out directly attributable to a decline in private donations is approximately 10 percent. Note that the results reported in columns 8 and 9 are sensitive to the inclusion/exclusion of a particular subset of environmental and youth organizations, respectively. Including environmental organizations but excluding the subset of organizations concerned with natural resources (column 10) results in coefficients that are similar to those reported for the base specification. Including youth development organizations but excluding the subset of organizations for boys and girls clubs (column 11) also results in coefficients that are similar to those reported for the base specification.

Overall, the various experiments reported in columns 2 to 11 in Table 5 support the basic conclusion of our preferred specification. 


\section{Discussion}

In this section we evaluate how our results compare to prior finding and to expectations we might form by looking at the actual practices of charities, and then go in to interpret how our results could shape future discussions of policy toward government grants to charities.

\section{Evaluating the Results}

Our results from Panel $A$ in Table 4 are quite similar to finding of Payne (1998), while the results of Panel $C$ are consistent with the findings of Andreoni and Payne (2003). The results of Panel $B$, by contrast, are unprecedented. How do our estimates of the return to fund-raising compare to what we might have expected?

An economist who is trained to look for profit maximization would be troubled to see from Panel $B$ that a dollar spent on fund-raising yields over five dollars of donations. Is this result reasonable?

First, there are strong reasons to believe that fund-raisers are not net revenue (profit) maximizers. Weisbrod (1988), for instance, observed that charities do not maximize net revenues and suggested that non-profits are "satisficers” that set fund-raising goals to meet other objectives. Because of the non-profit status of charities, the managers get no direct reward from maximizing revenues and cannot appropriate any of the surplus they might achieve. Moreover, pushing a charity to the envelope reduces the enjoyment of public service that charity managers might seek. ${ }^{17}$ Glaeser and Shleifer (2001) present a formal model of these ideas, arguing that firms choose non-profit status (rather than for-profit) in order to provide better quality

\footnotetext{
${ }^{17}$ Andreoni and Payne (2003) provide a model in which charity managers have a distaste for fund-raising that also generates a predictions that charities will not be observed to be net revenue maximizers (see also James, 1983). Another alternative would be a model in which individuals shop among charities based on ad hoc charity ratings which factor the fund-raising expenditures per dollar raised as a negative attribute. If these ratings affect the extensive margin for a subset of donors, then we could again see patterns as shown in our results.
} 
employment for themselves, which does not necessarily imply a desire for expanding program services or for building fund-raising "empires.”

Another reason they may not maximize net revenues is pressure from donors to keep fund-raising expenses low. For example, a popular guide to fund-raising (Greenfield, 2002) provides “cost-benefit standards and guidelines" for charities. These indicate that, depending on the fund-raising activity, a "mature" fund-raising program should expect 3 to 10 dollars of donations for each dollar spent on fund-raising (Exhibit 13.3, page 499). ${ }^{18}$ Likewise, the American Institute of Philanthropy, which provides independent quality ratings of nonprofits, states in its ratings criteria that, "\$35 or less to raise $\$ 100$ is reasonable for most charities," indicating a return of about $\$ 3$ per dollar spent as a minimum criteria for proper management. ${ }^{19}$ Give.org posts an identical standard. Similarly, the watchdog group Charity Navigator considers “fund-raising efficiency” of $\$ 2.5$ to $\$ 7$ raised per dollar spent to be acceptable, depending on the type of charity, and reports a median efficiency across all charities of \$10 raised per dollar spent. ${ }^{20}$ Charities who fail to reach these standards, as a consequence, receive low quality ratings and may see their donations suffer as a result.

One naturally should ask why these industry standards are set at these particular levels. It may be that donors confuse average and marginal costs of fund-raising, and the standards are arbitrary and inefficient. ${ }^{21}$ Another possibility is that these standards may be an attempt by the industry to collude on a lower level of fund-raising that protects the industry from "excessive"

\footnotetext{
${ }^{18}$ They indicate each dollar spent on direct mail should return $\$ 4$ to $\$ 5$, on "volunteer-led personal solicitations" and on "capital campaigns" should yield $\$ 5$ to $\$ 10$, and on planned giving should earn $\$ 3$ to $\$ 5$. See also Greenfield (2002).

${ }^{19}$ See the website for the American Institute of Philanthropy, http://www.charitywatch.org/cirteria.html .

20 See the website for Charity Navigator, on the page for their ratings tables, http://www.charitynavigator.org/index.cfm/bay/content.view/catid/2/cpid/48.htm

${ }^{21}$ Related to this issue is one that concerns whether we are able to estimate the true marginal effect of fundraising on private donations. The within effect of fundraising on private donations that we measured, may, in some instances reflect a local average effect more so than a marginal effect.
} 
and wasteful fund-raising that simply shifts donors between charities without "expanding the pie” of donor dollars available. A final possibility is that they are put on the managers as a constraint by the non-profit's board who, for whatever reason, see virtue in restraining fundraising. Identifying why the standards are set at this level, while an extremely interesting question for research, is beyond the scope of this study.

These various theories of non-profit governance and observations from industry observers should lead us to expect a value for B between 3 and 10 . The value we measure, around 5.6, is in line with the suggested return and "fund-raising efficiency" promoted by these industry experts and non-profit watchdogs.

It remains possible, however, that this coefficient is biased due to systematic underreporting of fundraising expenditures. In particular, if all charities systemically report a constant fraction of true fundraising expenses, then the returns to reported fundraising will be biased upward. To the extent that underreporting is heterogeneous and nonlinear, our charity fixed effect should minimize this concern, but it nonetheless cannot be ruled out.

\section{What Can be Done to Mitigate Crowding Out?}

What incentives or restrictions can the government put on its grants that could reduce or eliminate crowding out? Because our results show that the majority of crowding out is due to the actions of the charities themselves, and because fund-raising is still quite productive, the set of alternatives is potentially quite broad.

For example, our results show that, at least for some organizations, if the government adopted a policy that total spending by the charity must rise by 100 percent of the grant amount, charities could meet this goal simply by not altering their fund-raising activities in response to 
government grants. Myriad other policies, such as requiring private donations to match a fraction of government donations, are potentially feasible actions to remediate crowding out.

\section{The Relative Efficiency of Fund-Raising.}

What would be more efficient: a) A $\$ 10,000$ government grant to a charity that, because of crowding out, raises services of the charity by only $\$ 4100$; or $b$ ) An increase in fund-raising expenditure of the charity of $\$ 727$ that results in an increase in services of $\$ 4100$ ? The answer to this question depends on how the marginal cost of fund-raising compares to marginal cost of public funds, that is, the cost of collecting and spending the $\$ 10,000$ in tax dollars.

Economists have for many years attempted to measure the cost of collecting taxes. Snow and Warren (1996) summarize these. The cost of a dollar varies across studies from \$0.01 to \$0.31. One study (Ballard and Fullerton, 1992) even reports a negative cost of $-0.078 .^{22}$ Of those estimates reported in Snow and Warren, the median estimate (by Stuart, 1984) is 0.072.

In our example, let the cost of public funds be $k$. Then we would estimate that the $\$ 10,000$ grant would cost $\$ 10,000 k$ but would save $\$ 1370$ in reduced fund-raising. The government grant will reduce economic efficiency if $\$ 10,000 k-1370>727$, that is, if $k>$ $0.210 .^{23}$ While the median estimate for $k$ is below this critical value, the critical $k$ is still well

\footnotetext{
${ }^{22}$ The deadweight loss of wage taxes can be negative if, for instance, a worker is on the backward bending portion of the labor supply curve.

${ }^{23}$ This last example misses two important aspects of fund-raising however. First, as noted by Rose-Ackerman (1982), in a competitive market for donations, sometimes fundraising results in a shift of dollars from one charity to another rather than generating new dollars for the charitable sector. Suppose that of the $\$ 4100$ raised, a fraction $f$ of these dollars were diverted from other charities. Likewise, of the $\$ 5900$ that is crowded out by the grant, a fraction $f$ gets spent on other charities. Hence, moving to (a) from (b) there is a net increase charitable services of other charities of (5900-4100) $f=1800 \mathrm{f}$. Putting this in the equation, then the grant reduces efficiency if $\$ 10,000 k-1370$ $>727+1800 f$, that is, if $k>0.210+0.18 f$. Second, we need to add the average cost across all charities of applying for and administering these grants. No scholars to our knowledge have estimates of $f$ or of the application and administrative costs of grants, although both of these costs are certainly worthy of study.
} 
within the range of estimates the cost of public funds in the literature, making it difficult to determine whether crowding is welfare enhancing or welfare reducing. When one factors in the social costs and benefits of fund-raising (e.g. Andreoni and Rao, 2010), the answer becomes even more cloudy, but well worth pursuing in future research.

\section{Conclusion}

When a charity receives a government grant there can be two paths that lead to lower donations to the charity. First is direct crowding out of givers. Donors who count their contributions through taxation as part of their total contribution will reduce their voluntary contributions to offset the grant. The second path is by crowding out the fundraisers. If charity managers find fund-raising a "necessary evil," or fear it may hurt their evaluation from charity watchdog groups, then a government grant will allow them to redirect efforts from fund-raising to providing charitable services. This means that after getting a grant, charities may simply cut back fund-raising. If donors are largely unaware of fluctuations in the grants received by charities, then reductions in fund-raising becomes a sensible explanation for crowding out.

We explore these issues with an unbalanced panel of over 8000 charities from 1985 to 2002. Using instrumental variable techniques, we estimate total crowding is around 73 percent, and that this crowding out is almost exclusively is the result of reduced fund-raising. A $\$ 10,000$ grant, for instance, reduces fund-raising expenses by $\$ 1370$, which in turn reduces donations by $\$ 7271$. Adding this $\$ 1370$ savings in fund-raising expenses reduces the estimate of crowding out to 59 percent. If charities had maintained their fund-raising efforts, our estimates show that donations would have risen by the full amount of the grant.

Our study reveals that the actions of the charities themselves are responsible for essentially all of the crowding out. The implication is that there could be many avenues 
available to a government that wants to remediate crowding out. While there will be variation across charities, our results indicate that, in general, requirements that charities match a fraction of government grants with increases in private donations could be a feasible response to crowding out. Whether such a requirement is welfare enhancing is an open question and depends on what is assumed about the marginal cost of raising public funds.

This is, of course, the first study of its kind. As such, additional studies will be needed to establish the robustness of these results. The finding that crowding out is due to reduced fundraising by the charities opens up many new avenues for both researchers and policy makers to discover ways to understand and address crowding out. 


\section{References}

Andreoni, James. 1988. "Privately Provided Public Goods in a Large Economy: The Limits of Altruism.” Journal of Public Economics 35 (February): 57-73.

Andreoni, James. 1989. "Giving with Impure Altruism: Applications to Charity and Ricardian Equivalence.” Journal of Political Economy, 97 (December): 1447-58.

Andreoni, James. 1990. "Impure Altruism and Donations to Public Goods: A Theory of WarmGlow Giving.” Economic Journal, 100 (June): 464-77.

Andreoni, James. 1998. “Toward a Theory of Charitable Fund-raising.” Journal of Political Economy, 106 (December): 1186-1213.

Andreoni, James. 2006. "Philanthropy." in S-C. Kolm and J. Mercier Ythier, eds., Handbook of Giving, Reciprocity and Altruism, Amsterdam: North Holland: 1201-1269.

Andreoni, James. 2007. "Giving Gifts to Groups: How Altruism Depends on the Number of Recipients.” Journal of Public Economics, forthcoming.

Andreoni, James and A. Abigail Payne. 2003. "Do Government Grants to Private Charities Crowd Out Giving or Fund-raising?” American Economic Review, 93 (June): 792-812.

Andreoni, James and Justin M. Rao. 2010. "The Power of Asking: How Communication Affects Selfishness, Empathy, and Altruism." UCSD, April 2010.

Andrews, D., Moreira, M. and J. Stock. 2005. "Performance of Conditional Wald Tests in IV Regression with Weak Instruments," Journal of Econometrics, forthcoming.

Bound, John, David A. Jaeger, and Regina M. Baker. 1995. "Problems with Instrumental Variables Estimation When the Correlation between the Instruments and the Endogenous Explanatory Variables is Weak." Journal of the American Statistical Association, 90(430): 443-50.

Ballard C.L, and D. Fullerton. 1992. "Distortionary Taxation and the Provision of Public Goods." Journal of Economic Perspectives, (Summer): 117-131.

Bergstrom, Theodore, Lawrence Blume, and Hal Varian. 1985. "On the Private Provision of Public Goods.” Journal of Public Economics, 29 (February): 25-49.

Borgonovi, Francesca. 2006. "Do Public Grants to American Theatres Crowd-out Private Donations?” Public Choice, 126 (March): 429-451.

Clotfelter, Charles T. 1985. Federal Tax Policy and Charitable Giving. University of Chicago Press.

Cornes, R., and Sandler, T. 1984. "Easy Riders, Joint Production, and Public Goods." Economic Journal. 94: 580-98.

Glaeser, Edward L. and Andrei Shleifier. 2001. "Not-for-profit Entrepreneurs.” Journal of Public Economics, 81 (July): 99-115.

Greenfield, James M., ed., 2001. The Nonprofit Handbook: Fund-raising, Third Edition, John Wiley and Sons: New York.

Greenfield, James M.. 2002. Fundraising Fundamentals: A Guide to Annual Giving for Professionals and Volunteers, Second Edition. John Wiley and Sons: New York.

Gruber, Jonathan. 2004. Pay or pray? The Impact of Charitable Subsidies on Religious Attendance. Journal of Public Economics, 88 (December): 2635-2655.

Gruber, Jonathan and Daniel M. Hungerman. 2007. "Faith-based Charity and Crowd-out During the Great Depression” Journal of Public Economics, 91 (June): 1043-1069. 
Harbaugh, William T., Ulrich Mayr, and Daniel R. Burghart. 2007. "Neural Response to Taxation and Voluntary Giving Reveal Motives for Charitable Donations." Science, 316 (June): 1622-1625.

Hausman, Jerry. 1978. “Specification Tests in Econometrics.” Econometrica, 46 (November): 1251-1271.

Hungerman, D.M. 2005. "Are Church and State Substitutes? Evidence from the 1996 Welfare Reform." Journal of Public Economics, 89 (December): 2245-2267.

James, Estelle. 1983. "How nonprofits grow: A model.” Journal of Policy Analysis and Managemen, Volume 2, Issue 3, pages 350-365.

Khanna, Jyoti, John Posnett, and Todd Sandler. 1995. "Charity Donations in the UK: New Evidence Based on Panel Data.” Journal of Public Economics, 56 (February):257-272.

Kingma, Bruce Robert. 1989. "An Accurate Measurement of the Crowd-out Effect, Income Effect, and Price Effect for Charitable Contributions.” Journal of Political Economy. 97, (October): 1197-1207.

Manzoor, Sonia H. and John D. Straub. 2005. “The Robustness of Kingma's Crowd-out Estimate: Evidence from New Data on Contributions to Public Radio.” Public Choice, 123 (June): 463-476.

Moreira, M. 2003: "A Conditional Likelihood Ratio Test for Structural Models," Econometrica, 71 (July): 1027-1048.

Okten, Cagla and Burton A. Weisbrod. 2000. "Determinants of Donations in Private Nonprofit Markets.” Journal of Public Economics, 75 (July):255-272.

Payne, A. Abigail. 1998. "Does the Government Crowd-Out Private Donations? New Evidence From a Sample of Non-Profit Firms.” Journal of Public Economics, 69 (September): 323345.

Payne, A. Abigail. 2001. "Measuring the Effect of Federal Research Funding on Private Donations at Research Universities: Is Federal Research Funding More Than a Substitute for Private Donations?” International Tax and Public Finance, 8 (November): 731-51.

Ribar, David C. and Mark O.Wilhelm. 2002. "Altruistic and Joy-of-Giving Motivations in Charitable Behavior.” Journal of Political Economy, 110: 425-457.

Roberts, Russell D. 1984. "A Positive Model of Private Charity and Public Transfers.” Journal of Political Economy, 92 (February): 136-148.

Rose-Ackerman, Susan. 1982. “Charitable Giving and 'Excessive’ Fund-raising.” Quarterly Journal of Economics, 97 :195-212.

Schaffer, M.E., 2007. xtivreg2: Stata module to perform extended IV/2SLS, GMM and AC/HAC, LIML and k-class regression for panel data models.

Snow, A. and R.S. Warren. 1996. "The Marginal Welfare Cost of Public Funds: Theory and Estimates.” Journal of Public Economics, 61(August): 289-305.

Steinberg, R. 1987. "Voluntary Donations and Public Expenditures in a Federalist System." American Economic Review. 77: 24-36.

Stock, James H. and Mark W. Watson. 2006. "Heteroskedasticity-Robust Standard Errors for Fixed Effects Panel Data Regression,” mimeo, Princeton University.

Stuart, Charles. 1984. "Welfare Costs Per Dollar of Additional Tax Revenue in the United States.” American Economic Review, 74 : 352-362.

Warr, P.G. 1982. "Pareto Optimal Redistribution and Private Charity." Journal of Public Economics, 19 (October):131-138.

Weisbrod, Burton A. 1988. The Nonprofit Economy. Harvard University Press: Cambridge, MA. 
Weisbrod, Burton A. 1998. "Modelling the Nonprofit Organization as a Multiproduct Firm: A Framework for Choice.” in B.A. Weisbrod, ed., To Profit or Not to Profit: The Commercial Transformation of the Nonprofit Sector. Cambridge: Cambridge University Press.

Weisbrod, Burton A. and Nestor D. Dominguez. 1986. "Demand for Collective Goods in Private Nonprofit Markets: Can Fund-raising Expenditures Help Overcome Free-Rider Behavior?” Journal of Public Economics, 30 (June): 83-96.

Wooldridge, Jeffrey M. 2002. Econometric Analysis of Cross Section and Panel Data. Cambridge, Mass.:MIT Press. 
Table 1: Distribution of Charities Under Analysis

\begin{tabular}{|c|c|c|c|c|c|c|c|c|}
\hline Type of Organization & $\begin{array}{c}\text { \# of Firms } \\
\text { Studied }\end{array}$ & $\begin{array}{l}\% \text { of Firms wl } \\
\text { 3+obs }\end{array}$ & $\begin{array}{c}\text { \# of Observations } \\
\text { Studied }\end{array}$ & $\begin{array}{c}\% \text { of Total } \\
\text { Observations for } \\
\text { Firms with } 3+ \\
\text { observations } \\
\end{array}$ & $\begin{array}{c}\text { Private } \\
\text { Donations }\end{array}$ & $\begin{array}{l}\text { Fundraising } \\
\text { Expenditures }\end{array}$ & $\begin{array}{l}\text { Government } \\
\text { Grants }\end{array}$ & $\begin{array}{l}\text { Revenues From } \\
\text { Dues }\end{array}$ \\
\hline $\begin{array}{l}\text { NTEE Group I } \\
\text { Crime \& Legal Related }\end{array}$ & 681 & $25.4 \%$ & 3191 & $25.9 \%$ & $\begin{array}{l}\$ 593.41 \\
(2991.85)\end{array}$ & $\begin{array}{c}\$ 94.10 \\
(670.48)\end{array}$ & $\begin{array}{l}\$ 878.64 \\
(2468.48)\end{array}$ & $\begin{array}{c}\$ 22.17 \\
(291.50)\end{array}$ \\
\hline $\begin{array}{l}\text { NTEE Group J } \\
\text { Employment }\end{array}$ & 321 & $14.4 \%$ & 1547 & $14.6 \%$ & $\begin{array}{l}\$ 585.38 \\
(1514.97)\end{array}$ & $\begin{array}{l}\$ 69.08 \\
(200.21)\end{array}$ & $\begin{array}{l}\$ 1,822.22 \\
(11415.93)\end{array}$ & $\begin{array}{l}\$ 5.56 \\
(71.17)\end{array}$ \\
\hline $\begin{array}{l}\text { NTEE Group K } \\
\text { Food, Agriculture, Nutrition }\end{array}$ & 408 & $27.5 \%$ & 1949 & $28.4 \%$ & $\begin{array}{l}\$ 3,546.38 \\
(7423.06)\end{array}$ & $\begin{array}{l}\$ 99.19 \\
(214.86)\end{array}$ & $\begin{array}{l}\$ 555.93 \\
(1351.28)\end{array}$ & $\begin{array}{c}\$ 5.37 \\
(27.84)\end{array}$ \\
\hline $\begin{array}{l}\text { NTEE Group L } \\
\text { Housing \& Shelter }\end{array}$ & 1,225 & $18.8 \%$ & 5795 & $18.9 \%$ & $\begin{array}{l}\$ 385.45 \\
(989.73)\end{array}$ & $\begin{array}{c}\$ 42.01 \\
(134.27)\end{array}$ & $\begin{array}{l}\$ 356.60 \\
(1191.58)\end{array}$ & $\begin{array}{l}\$ 1.12 \\
(19.49)\end{array}$ \\
\hline $\begin{array}{l}\text { NTEE Group P } \\
\text { Human Services }\end{array}$ & 4,561 & $20.5 \%$ & 23,275 & $20.8 \%$ & $\begin{array}{l}\$ 739.68 \\
(2626.29)\end{array}$ & $\begin{array}{l}\$ 112.48 \\
(531.55)\end{array}$ & $\begin{array}{l}\$ 1,071.24 \\
(3975.69)\end{array}$ & $\begin{array}{l}\$ 214.00 \\
(1494.59)\end{array}$ \\
\hline $\begin{array}{l}\text { NTEE Group S } \\
\text { Community Improvement }\end{array}$ & 866 & $13.6 \%$ & 4012 & $13.9 \%$ & $\begin{array}{l}\$ 528.85 \\
(2503.39)\end{array}$ & $\begin{array}{l}\$ 39.35 \\
(187.01)\end{array}$ & $\begin{array}{l}\$ 574.41 \\
(1819.03)\end{array}$ & $\begin{array}{l}\$ 11.56 \\
(126.44)\end{array}$ \\
\hline Total, All Organizations & 8062 & $19.5 \%$ & 39769 & $19.8 \%$ & $\begin{array}{c}\$ 786.61 \\
(2954.16)\end{array}$ & $\begin{array}{l}\$ 91.02 \\
(905.49)\end{array}$ & $\begin{array}{l}\$ 905.49 \\
(3942.77)\end{array}$ & $\begin{array}{l}\$ 128.83 \\
(1151.67)\end{array}$ \\
\hline
\end{tabular}

Note: 1,000 s of dollars. Standard deviations reported in parenthesis. All dollars are real (2000 base year)

See discussion in paper regarding sample selection 


\begin{tabular}{|c|c|c|c|c|}
\hline & $\begin{array}{l}\text { Mean } \\
(1)\end{array}$ & $\begin{array}{c}\text { Std. Deviation } \\
\text { (2) }\end{array}$ & $\begin{array}{c}\text { Minimum } \\
\text { (3) }\end{array}$ & $\begin{array}{c}\text { Maximum } \\
\text { (4) }\end{array}$ \\
\hline $\begin{array}{l}\text { State Level Control Measures } \\
\text { Per Capita Income }(/ 1000) \\
\text { Total Population (1000s) } \\
\% \text { of Population under } 18 \\
\% \text { Population over } 65\end{array}$ & $\begin{array}{c}\$ 29.34 \\
11,380 \\
25.07 \\
12.59\end{array}$ & $\begin{array}{l}(4.03) \\
(9451) \\
(2.17) \\
(1.81)\end{array}$ & $\begin{array}{c}\$ 14.21 \\
491 \\
15.59 \\
8.53\end{array}$ & $\begin{array}{l}\$ 41.96 \\
34,988 \\
33.43 \\
18.55\end{array}$ \\
\hline $\begin{array}{l}\text { Democratic Governor } \\
\text { Share of State Caucus (US House of Representatives) by Democratic Party } \\
\text { Government Transfers Under Medicare Program (/1000) } \\
\text { Government Transfers Under Medicaid Program }(/ 1000) \\
\text { Government Transfers for Income Maintenance }(/ 1000)\end{array}$ & $\begin{array}{r}0.66 \\
0.50 \\
\$ 9,187.40 \\
\$ 9,123.68 \\
\$ 5,011.63\end{array}$ & $\begin{array}{c}(0.48) \\
(0.21) \\
(7652.10) \\
(9262.04) \\
(4423.67) \\
\end{array}$ & $\begin{array}{r}0.00 \\
0.00 \\
\$ 195.17 \\
\$ 131.23 \\
\$ 107.12 \\
\end{array}$ & $\begin{array}{r}1.00 \\
1.00 \\
\$ 28,527.08 \\
\$ 36,654.34 \\
\$ 20,007.39 \\
\end{array}$ \\
\hline $\begin{array}{l}\text { Instruments for Government grants } \\
\text { (state level measures) } \\
\text { Total Years of Experience of Congressional Respresentatives Affiliated with } \\
\text { Democratic Party } \\
\text { Total Years of Experience of Congressional Respresentatives Affiliated with } \\
\text { Republican Party } \\
\text { Experience of Representatives Affiliated with Political Party with Most } \\
\text { Representatives - Experience of Other Representatives }\end{array}$ & $\begin{array}{l}88.11 \\
64.69 \\
39.05\end{array}$ & $\begin{array}{l}(87.03) \\
(50.02) \\
(47.23)\end{array}$ & $\begin{array}{c}0.00 \\
0.00 \\
-34.00\end{array}$ & $\begin{array}{l}316 \\
189 \\
147\end{array}$ \\
\hline $\begin{array}{l}\text { Instruments for Fundraising Expenditures } \\
\text { Liabilities (/1000) } \\
\text { Total Occupancy Expenses (/1000) }\end{array}$ & $\begin{array}{c}\$ 1,183.40 \\
\$ 152.98\end{array}$ & $\begin{array}{c}(6645.45) \\
(551.76)\end{array}$ & $\begin{array}{l}-\$ 216.11 \\
-\$ 136.41\end{array}$ & $\begin{array}{l}345854.8 \\
14164.49\end{array}$ \\
\hline
\end{tabular}


Table 3: Coefficients on Instruments from First Stage Regression

\begin{tabular}{l|c|c}
\hline Dependent Variable & $\begin{array}{c}\text { Government } \\
\text { Grants } \\
(1)\end{array}$ & $\begin{array}{c}\text { Fundraising } \\
\text { Expenditures } \\
(3)\end{array}$ \\
\hline Total Years of Experience of Congressional Respresentatives & $\mathbf{3 . 6 4 1}$ & \\
Affiliated with Democratic Party & $(1.942)$ & \\
Experience of Representatives Affiliated with Political Party with Most & & \\
Representatives - Experience of Other Representatives & $\mathbf{- 3 . 1 6 4}$ & \\
& $(1.206)$ & \\
Liabilities & & $\mathbf{0 . 0 1 3}$ \\
Total Occupancy Expenses & & $(0.002)$ \\
F-Test of Instruments & & $\mathbf{0 . 1 0 5}$ \\
(p-value) & 7.13 & $(0.036)$ \\
\hline
\end{tabular}

Note: all regressions include firm fixed effects, year effects, state level time-varying measures, and firm level time varying measures

Robust standard errors are reported in parentheses. A coefficient in bold is significant at a $p$-value $<.05$ 
Table 4: Analysis of Fundraising and Donor Behavior

\begin{tabular}{|c|c|c|c|c|}
\hline & (1) & (3) & (4) & (5) \\
\hline $\begin{array}{l}\text { Panel A: Effects of Government Fundir } \\
\text { Donations } \\
\text { Dependent Variable (Private Donations) }\end{array}$ & OLS & LIML & 2SLS & GMM \\
\hline $\begin{array}{l}\text { Government Grants } \\
\text { (Robust Standard Error) }\end{array}$ & $\begin{array}{c}0.025 \\
(0.027)\end{array}$ & $\begin{array}{l}-0.757 \\
(0.295)\end{array}$ & $\begin{array}{l}-0.756 \\
(0.295)\end{array}$ & $\begin{array}{l}-0.758 \\
(0.295)\end{array}$ \\
\hline $\begin{array}{l}\text { Program Dues Received by Charity } \\
\text { (Robust Standard Error) }\end{array}$ & $\begin{array}{c}\mathbf{0 . 1 7 6} \\
(0.053)\end{array}$ & $\begin{array}{c}0.193 \\
(0.073)\end{array}$ & $\begin{array}{c}0.193 \\
(0.073)\end{array}$ & $\begin{array}{c}\mathbf{0 . 1 9 4} \\
(0.073)\end{array}$ \\
\hline $\begin{array}{l}\text { Overidentification Test for Instruments } \\
\text { Chi-Square Statistic } \\
\text { (p-value) }\end{array}$ & & $\begin{array}{c}0.013 \\
(0.908) \\
\end{array}$ & $\begin{array}{c}0.013 \\
(0.908) \\
\end{array}$ & $\begin{array}{c}0.013 \\
(0.908)\end{array}$ \\
\hline $\begin{array}{l}\text { Panel B: Effects of Fundraising Expenc } \\
\text { Private Donations } \\
\text { Dependent Variable (Private Donations) } \\
\text { Fundraising Expenditures } \\
\text { (Robust Standard Error) }\end{array}$ & $\begin{array}{l}\text { OLS } \\
\mathbf{3 . 3 8 1} \\
(0.466)\end{array}$ & $\begin{array}{l}\text { LIML } \\
\mathbf{5 . 6 4 4} \\
(0.954)\end{array}$ & $\begin{array}{c}2 S L S \\
5.624 \\
(0.944)\end{array}$ & $\begin{array}{l}\text { GMM } \\
\mathbf{5 . 7 4 7} \\
(0.937)\end{array}$ \\
\hline $\begin{array}{l}\text { Program Dues Received by Charity } \\
\text { (Robust Standard Error) }\end{array}$ & $\begin{array}{c}\mathbf{0 . 0 9 5} \\
(0.043)\end{array}$ & $\begin{array}{l}0.041 \\
(0.064)\end{array}$ & $\begin{array}{c}0.041 \\
(0.064)\end{array}$ & $\begin{array}{l}0.030 \\
(0.064)\end{array}$ \\
\hline $\begin{array}{l}\text { Overidentification Test for Instruments } \\
\text { Chi-Square Statistic } \\
\text { (p-value) }\end{array}$ & & $\begin{array}{r}1.188 \\
(0.276) \\
\end{array}$ & $\begin{array}{r}1.195 \\
(0.274) \\
\end{array}$ & $\begin{array}{c}1.195 \\
(0.274) \\
\end{array}$ \\
\hline $\begin{array}{l}\text { Panel C: Effects of Government Fundir } \\
\text { Fundraising Expenditures } \\
\text { Dependent Variable (Private Donations) } \\
\text { Government Grants } \\
\text { (Robust Standard Error) }\end{array}$ & $\begin{array}{l}\text { OLS } \\
\mathbf{0 . 0 0 9} \\
(0.004)\end{array}$ & $\begin{array}{l}\text { LIML } \\
-\mathbf{0 . 1 4 1} \\
(0.050)\end{array}$ & $\begin{array}{l}2 S L S \\
-0.141 \\
(0.050)\end{array}$ & $\begin{array}{c}\text { GMM } \\
-0.142 \\
(0.049)\end{array}$ \\
\hline $\begin{array}{l}\text { Program Dues Received by Charity } \\
\text { (Robust Standard Error) }\end{array}$ & $\begin{array}{c}\mathbf{0 . 0 2 4} \\
(0.006)\end{array}$ & $\begin{array}{c}\mathbf{0 . 0 2 7} \\
(0.006)\end{array}$ & $\begin{array}{c}\mathbf{0 . 0 2 7} \\
(0.006)\end{array}$ & $\begin{array}{c}\mathbf{0 . 0 2 7} \\
(0.006)\end{array}$ \\
\hline $\begin{array}{l}\text { Overidentification Test for Instruments } \\
\text { Chi-Square Statistic } \\
\text { (p-value) }\end{array}$ & & $\begin{array}{c}0.058 \\
(0.809)\end{array}$ & $\begin{array}{c}0.058 \\
(0.809)\end{array}$ & $\begin{array}{c}0.058 \\
(0.809)\end{array}$ \\
\hline
\end{tabular}

Note: All analyses include a set of time-varying state and/or county level measures, year dummies, and organization fixed effects Robust standard errors are reported in parentheses. A coefficient in bold is significant at a $p$-value $<.05$ 
Table 5: Total, Direct, and Indirect (due to Fund-raising) Crowding Out

\begin{tabular}{|c|c|c|c|c|c|c|c|c|c|c|c|}
\hline & $\begin{array}{l}(1) \\
\text { Base }\end{array}$ & $\begin{array}{c}\text { (2) } \\
\text { Includes } \\
\text { Charities } \\
\text { with 0 Govt } \\
\text { Grants for } \\
\text { All Years }\end{array}$ & $\begin{array}{c}(3) \\
\text { Excludes } \\
\text { Crime } \\
\text { Charities (I) } \\
\end{array}$ & $\begin{array}{c}(4) \\
\text { Excludes } \\
\text { Employment } \\
\text { Charities } \\
\text { (J) }\end{array}$ & $\begin{array}{c}(5) \\
\text { Excludes } \\
\text { Food } \\
\text { Charities } \\
(\mathrm{K})\end{array}$ & $\begin{array}{c}(6) \\
\text { Excludes } \\
\text { Housing } \\
\text { Charities } \\
\text { (L) }\end{array}$ & $\begin{array}{c}\text { (7) } \\
\text { Excludes } \\
\text { Community } \\
\text { Charities } \\
\text { (S) }\end{array}$ & $\begin{array}{c}(8) \\
\text { Includes } \\
\text { Environment } \\
\text { Charities } \\
\text { (C) }\end{array}$ & $\begin{array}{c}(9) \\
\text { Includes } \\
\text { Youth } \\
\text { Development } \\
\text { Charities } \\
\text { (O) }\end{array}$ & $\begin{array}{c}(10) \\
\text { Includes } \\
\text { Environment } \\
\text { Charities (C); } \\
\text { excludes C3 } \\
\text { orgs (368) }\end{array}$ & $\begin{array}{c}(11) \\
\text { Includes Youth } \\
\text { Development } \\
\text { Charities (O) } \\
\text { excludes O2 } \\
\text { orgs (524) }\end{array}$ \\
\hline $\begin{array}{l}\text { Panel } \boldsymbol{A} \\
\text { A : dD/dG = Changed donations by grants } \\
\text { Significantly different from Base Organizations? } \\
B: \mathrm{dD} / \mathrm{dF}=\text { Changed donations by fundraising } \\
\text { Significantly different from Base Organizations? } \\
C: \mathrm{dF} / \mathrm{dG}=\text { Changed fund-raising by grants } \\
\text { Significantly different from Base Organizations? }\end{array}$ & $\begin{array}{l}-0.757 \\
5.644 \\
-0.141\end{array}$ & $\begin{array}{l}-1.233 \\
\text { No } \\
5.101 \\
\text { No } \\
-0.206 \\
\text { No } \\
\end{array}$ & $\begin{array}{c}-0.548 \\
\text { No } \\
5.695 \\
\text { No } \\
-0.077 \\
\text { Yes* }^{*} \\
\end{array}$ & $\begin{array}{c}-0.656 \\
\text { No } \\
5.525 \\
\text { No } \\
-0.127 \\
\text { No } \\
\end{array}$ & $\begin{array}{c}-0.570 \\
\text { No } \\
5.654 \\
\text { No } \\
-0.133 \\
\text { No } \\
\end{array}$ & $\begin{array}{c}-0.768 \\
\text { No } \\
5.666 \\
\text { No } \\
-0.142 \\
\text { No } \\
\end{array}$ & $\begin{array}{l}-0.579 \\
\text { No } \\
4.278 \\
\text { No** } \\
-0.116 \\
\text { No } \\
\end{array}$ & $\begin{array}{c}-1.262 \\
\text { No } \\
6.029 \\
\text { No } \\
-0.150 \\
\text { No } \\
\end{array}$ & $\begin{array}{c}-1.243 \\
\text { No } \\
5.862 \\
\text { No } \\
-0.189 \\
\text { No } \\
\end{array}$ & $\begin{array}{c}-0.724 \\
\text { No } \\
5.822 \\
\text { No } \\
-0.129 \\
\text { No } \\
\end{array}$ & $\begin{array}{c}-0.809 \\
\text { No } \\
5.907 \\
\text { No } \\
-0.143 \\
\text { No } \\
\end{array}$ \\
\hline $\begin{array}{l}\text { Panel B } \\
\text { Crowding out of Donations } \\
\text { Total Crowd Out }=A\end{array}$ & -0.757 & -1.233 & -0.548 & -0.656 & -0.570 & -0.768 & -0.579 & -1.262 & -1.243 & -0.724 & -0.809 \\
\hline $\begin{array}{l}\text { Direct Crowd Out }=A-B^{\star} C \\
\text { Percent }\end{array}$ & $\begin{array}{c}0.041 \\
-5 \%\end{array}$ & $\begin{array}{l}-0.182 \\
15 \%\end{array}$ & $\begin{array}{l}-0.109 \\
20 \%\end{array}$ & $\begin{array}{l}0.045 \\
-7 \%\end{array}$ & $\begin{array}{l}0.182 \\
-32 \%\end{array}$ & $\begin{array}{c}0.035 \\
-5 \%\end{array}$ & $\begin{array}{l}-0.085 \\
15 \%\end{array}$ & $\begin{array}{l}-0.358 \\
28 \%\end{array}$ & $\begin{array}{l}-0.137 \\
11 \%\end{array}$ & $\begin{array}{c}0.026 \\
-4 \%\end{array}$ & $\begin{array}{c}0.036 \\
-4 \%\end{array}$ \\
\hline $\begin{array}{l}\text { Indirect Crowd Out }=B^{\star} C \\
\text { Percent }\end{array}$ & $\begin{array}{r}-0.798 \\
105 \% \\
\end{array}$ & $\begin{array}{c}-1.051 \\
85 \% \\
\end{array}$ & $\begin{array}{l}-0.439 \\
80 \% \\
\end{array}$ & $\begin{array}{l}-0.701 \\
107 \% \\
\end{array}$ & $\begin{array}{l}-0.752 \\
132 \%\end{array}$ & $\begin{array}{l}-0.803 \\
105 \% \\
\end{array}$ & $\begin{array}{c}-0.494 \\
85 \% \\
\end{array}$ & $\begin{array}{l}-0.905 \\
72 \% \\
\end{array}$ & $\begin{array}{c}-1.106 \\
89 \%\end{array}$ & $\begin{array}{l}-0.750 \\
104 \% \\
\end{array}$ & $\begin{array}{l}-0.845 \\
104 \%\end{array}$ \\
\hline $\begin{array}{l}\text { Panel C } \\
\text { Crowding out of Spending (adding back saving } \\
\text { from reduced fund-raising). } \\
\text { Total Crowd Out }=A-C\end{array}$ & -0.615 & -1.027 & -0.471 & -0.529 & -0.437 & -0.626 & -0.464 & -1.112 & -1.055 & -0.595 & -0.666 \\
\hline $\begin{array}{l}\text { Direct Crowd Out }=A-B^{\star} C \\
\text { Percent }\end{array}$ & $\begin{array}{l}0.041 \\
-7 \%\end{array}$ & $\begin{array}{c}-0.182 \\
18 \%\end{array}$ & $\begin{array}{l}-0.109 \\
23 \%\end{array}$ & $\begin{array}{l}0.045 \\
-8 \%\end{array}$ & $\begin{array}{l}0.182 \\
-42 \%\end{array}$ & $\begin{array}{c}0.035 \\
-6 \%\end{array}$ & $\begin{array}{l}-0.085 \\
18 \%\end{array}$ & $\begin{array}{l}-0.358 \\
32 \%\end{array}$ & $\begin{array}{l}-0.137 \\
13 \%\end{array}$ & $\begin{array}{l}0.026 \\
-4 \%\end{array}$ & $\begin{array}{l}0.036 \\
-5 \%\end{array}$ \\
\hline $\begin{array}{l}\text { Indirect Crowd Out }=B^{\star} C-C \\
\text { Percent }\end{array}$ & $\begin{array}{l}-0.657 \\
107 \%\end{array}$ & $\begin{array}{c}-0.845 \\
82 \%\end{array}$ & $\begin{array}{c}-0.362 \\
77 \%\end{array}$ & $\begin{array}{c}-0.574 \\
108 \%\end{array}$ & $\begin{array}{l}-0.619 \\
142 \%\end{array}$ & $\begin{array}{l}-0.661 \\
106 \%\end{array}$ & $\begin{array}{c}-0.379 \\
82 \%\end{array}$ & $\begin{array}{l}-0.755 \\
68 \%\end{array}$ & $\begin{array}{l}-0.917 \\
87 \%\end{array}$ & $\begin{array}{l}-0.621 \\
104 \%\end{array}$ & $\begin{array}{l}-0.702 \\
105 \%\end{array}$ \\
\hline
\end{tabular}

Note: Estimates in Panel A, column 1 is from columns 2 \& 3 of Table 4; more detailed results for columns 2 - 9 are available from the authors. Coefficients in bold are statistically significant at $p<0.05$

${ }^{*} \mathrm{dF} / \mathrm{dG}$ in column 3 is signficantly different from the base regressions is attributable to the organizations classified as I2 organizations (Crime Prevention: Youth Violence/Drunk Driving types of charities)

$* \star \mathrm{dD} / \mathrm{dF}$ coefficient is different from the coefficient reported in column 1 at a $\mathrm{p}$-value of 0.1024

NTEE C3 Organizations cover natural resources and conservation protection activities; NTEE O2 Organizations cover boys and girls clubs 